\title{
PEMBERDAYAAN PETANI OLEH ORMAS MENURUT TINGKAT PARTISIPASI DI KABUPATEN BANDUNG
}

\section{EMPOWERMENT OF FARMERS BY ORMAS BASE ON PARTICIPATION LEVEL IN BANDUNG REGENCY}

\section{Utan Sahiro Ritonga}

\author{
Universitas Muhammadiyah Bandung, Jl. Soekarno-Hatta No.752 Kota Bandung \\ *E-mail: utanritonga@umbandung.ac.id \\ (Diterima 25-05-2021; Disetujui 05-07-2021)
}

\begin{abstract}
ABSTRAK
Saat ini program pemberdayan masyarakat telah menjadi bagian misi ormas keagamaan di Indonesia. Sebagai unsur non pemerintah dan bukan organisasi berorientasi bisnis perlu mengetahui kinerja program pemberdayaan tersebut menurut tingkat partisipasi petani. Dengan pendekatan penelitian deskripsi secara kuantitatif menggunakan kuesioner dalam pengumpulan data survei, diperoleh sebanyak 75 responden yang diambil di Kabupaten Bandung dengan teknik purposive sampling. Berdasarkan hasil perhitungan kumulatif diketahui partisipasi petani pada program pemberdayaan dalam kategori sedang pada kegiatan sosialisasi, dan kategori rendah pada kegiatan implementasi program. Hasil uji chi square pearson dan uji gamma diketahui usia petani memiliki korelasi secara positif dengan partisipasi dalam kegiatan implementasi, sementara pendidikan, penghasilan dan status petani memiliki korelasi yang negatif dengan partisipasi dalam kegiatan implementasi program. Karakteristik petani yang berkorelasi dengan partisipasi kegiatan perlu ditinjau oleh suatu ormas sebelum melaksanakan program pemberdayaan sebagai suatu strategi untuk keberhasilan program secara partisipatif.
\end{abstract}

Kata kunci: partisipasi petani, pemberdayaan petani, organisasi masyarakat, karakteristik petani

\section{ABSTRACT}

Currently empowerment program has become a mission of religion community organizations in Indonesia. As non government element and non business oriented organization it is necessary to know performance of empowerment programs based of farmer participation level. With a quantitative descriptive research approach using questionnaire in collecting of data survey were obtained 75 respondents taken with purposive sampling technique in Bandung Regency. Based results of cumulative calculations, known that farmer participation in empowerment program into middle category for socialization activity and low category for implementation activity of programs. Chi square pearson's and gamma test known were farmer age has positively correlated to participation in activity of program implementing, meanwhile education, income, and farmer status has negatively correlated to farmer participation for avtivity implementation of programs. Farmer characteristic has correlated to participation required by ormas before conducting of empowerment program as a strategic to success of program likely participatory.

Keywords: community organizations, farmer characteristic, farmer empowerment, farmer participation

\section{PENDAHULUAN}

Perubahan sosial secara terencana serta terarah menurut pengertiannya adalah suatu upaya dengan perencanaan untuk melakukan modifikasi berbagai sikap individu maupun kelompok yang menjadi sasaran. Dilakukan oleh para agen (Pemerintah, LSM, dan kelompok 


\section{PEMBERDAYAAN PETANI OLEH ORMAS MENURUT TINGKAT PARTISIPASI \\ DI KABUPATEN BANDUNG \\ Utan Sahiro Ritonga}

masyarakat) meliputi birokrasi publik (dalam struktur pemerintahan) dan birokrasi privat (dalam organisasi swasta) dengan memperkenalkan ide baru atau inovasi kedalam sistem sosial (Mulyadi, 2015). Hal tersebut berlaku pada organisasi-organisasi yang tidak memiliki kepentingan politik atau motif ekonomi seperti ormas yang mampu mengelolanya dengan baik serta memaksimalkan potensi yang ada di masyarakat maupun organisasi yang lahir di masyarakat (Mulyadi, 2012).

Untuk menciptakan pembangungan yang inklusif dan merata diperlukan aksi berkelanjutan dari kolaboratif dunia akademik, sektor bisnis, pemerintah, ormas, LSM dan khalayak secara luas. Nahdhatul Ulama (NU), Muhammadiyah dan Persatuan Islam (Persis) merupakan ormas keagaam yang juga menjadi organisasi sosial. Keberadaannya dituntut untuk berperan secara nyata menginspirasi memajukan umat melalui peran dibidang ekonomi, sosial, dan budaya serta (Suparman, 2012).

Seperti yang dikemukan oleh Jurdi (2011) bahwa Muhammadiyah salah satu gerakan sosial Islam yang beraktivitas lebih dari hanya sekedar menggiatkan bidang meliputi agama, pendidikan, kesehatan, sosial dan ekonomi, tetapi terus-menerus melaksanakan berbagai aktivitas untuk mentransformasikan keadaan masyarakat menuju strata yang lebih baik (Setyawan, 2013). Strategi partisipatif dimaksudkan dengan pelibatan secara bottom-up struktur organisasi dan warga Muhammadiyah untuk melaksanakan program pemberdayaan ekonomi, baik untuk warga persyarikatan maupun masyarakat umum untuk mewujudkan efektifitas program Majelis Ekonomi dan Kewirausahaan.

Menurut Anantanyu (2011), partisipasi dari petani dalam lembaga lokal menjadi manifestasi keberdayaan masyarakat dengan peningkatan melalui peran pemerintah, swasta, dan kelembagaan lain). Syahyuti (2012) juga menyebutkan berdasarkan analisis kelembagaan dengan inti perhatiannya relasi sosial bahwa petani dalam mengorganisasikan diri menjalankan usahanya dengan pola yang tidak terlalu kaku seperti organisasi formal. Bagi petani organisasi formal hanyalah salah satu pilihan, atau cederung hanya sebagai tindakan individual. Pedoman petani menjalankan usahanya adalah norma dan regulasi, dengan menjalin relasi sosial dengan berbagai pihak dalam norma komunitas, norma ekonomi, pasar, dan 
relasi dengan petugas pemerintah. Sementara organisasi secara formal seperti gapoktan dan koperasi merupakan salah satu sumber daya yang dimanfaatkan petani bersama unsur kelembagaan sebagai peluang, pedoman, serta batasan untuk berperilaku seharihari.

Partisipatory on farm dan lintas sektoral sebagai pendekatan untuk memberdayakan petani dapat dilakukan dalam pembangunan pertanian. Fokus pendekatan dilaksanakan untuk mendukung sumberdaya lokal, memperhatikan kondisi ekologi dari kultural secara holistic, integratif, berkesinambungan, memaksimaliskan pemanfaatan kearifan lokal yang dapat diadopsi petani (Elizabeth, 2008). Partisipasi merupakan keterlibatan masyarakat dalam kegiatan atau program pembangunan dengan inisiatif yang bisa berasal dari luar anggota masyarakat atau muncul dalam masyarakat sendiri (Suprayitno et al., 2015), dimana partisipasi dimulai dari perencanaan, pelaksanaan dan evaluasi (Putri et al., 2019). Pergerakan partisipasi petani membutuhkan pendekatan rasional menurut motivasi sosial, ekonomi, dan budaya yang menjadi bagian penting dalam meningkatkan produksi dan produktivitas (Zakaria, 2010). Selaras dengan peralihan paradigma pembangunan dari production centered development ke people centered development, maka salah satu prinsip yang harus dilaksanakan adalah partisipasi (Sriati et al., 2017).

Keberdayaan masyarakat dapat diwujudkan melalui partisipasi aktif masyarakat yang difasilitasi dengan adanya pelaku pemberdayaan (Widjajanti, 2011). Menurut Ramadoan et al., (2013) partisipasi tidak hanya dipengaruhi oleh faktor eksternal tetapi juga dipengaruhi karakteristik individu dari dalam masyarakat. Karakteristik adalah ciri khusus sesuai pembawaan tiap individu sebagai pembeda satu sama lainnya yang disebutkan oleh Wati et al., (2020) yang sama dengan penelitian Sukanata et al., (2015) yaitu umur, pendidikan, pengalaman yang merupakan gambaran kondisi individu sebagai anggota kelompok tani, dan sebagai pelaku usahatani. Hapsari \& Kinseng, (2018) mengukur tingkat pendapatan petani sebagai karakterisitik yang berhubungan dengan keaktifan peserta dalam berpartisipasi sama seperti penelitian Ramadoan et al., (2013) yang menyebutkan status petani pada lahan garapan menentukan petani untuk 


\section{PEMBERDAYAAN PETANI OLEH ORMAS MENURUT TINGKAT PARTISIPASI \\ DI KABUPATEN BANDUNG \\ Utan Sahiro Ritonga}

berpartisipasi dalam sebuah program pemberdayaan.

Mengetahui tingkat partisipasi petani yang tidak terlepas dari karakteristik petani menjadi semakin penting karena menurut Kehik, (2018) untuk merumuskan kebijakan dalam pengembangan kegiatan pemberdayaan yang telah dilakukan maka hal utama yang penting diketahui adalah gambaran sejauh mana pelaksanaan program telah berjalan. Tujuannya agar sinergis diantara pelaku teknis terkait seperti yang dikemukan oleh Iqbal, (2007) yakni pemerintah daerah, petani, pihak swasta, masyarakat, dan pemangku kepentingan (stakeholders) lainnya dapat diimplementasikan dalam pembangunan pertanian sebagai salah satu tulang punggung pembangunan nasional.

\section{METODE PENELITIAN}

Secara deskriptif penelitian ini memberikan gambaran bersifat situasional tingkat partisipasi petani dalam pelaksanaan program pemberdayaan yang dilakukan ormas di Kabupaten Bandung, dengan klasifikasi penelitian menurut teknik pengumpulan data secara kuantitatif menggunakan pendekatan survei melalui kuesioner sebagai instrumen penelitian.
Pengambilan sampel pada penelitian ini dilakukan secara purposive sampling (Priyono, 2016), dengan menetapkan jumlah petani yang pernah terlibat aktifitas ormas dalam hal ini Persyarikatan Muhammadiyah minimal sebanyak 75 orang sesuai informasi yang diperoleh bahwa petani yang pernah mengikuti kegiatan yang dilakukan mencapai jumlah tersebut.

Teknik analisa data untuk mengetahui tingkat partisipasi petani menggunakan perhitungan sebagai sebagai berikut:

$x=(1 \times \mathrm{n}+2 \times \mathrm{n}+3 \times \mathrm{n})$

Keterangan:

$x=$ Skor pada indikator

$\mathrm{n}=$ Jumlah jawaban

Perolehan skor pertisipasi pada kegiatan kemudian diklasifikasikan menurut kategori yang ditetapkan menggunakan perhitungan (Palar et al., 2019) dengan rumus berikut:

$$
r=\frac{\text { nilai skor max }- \text { nilai skor } \min }{\text { jumlah kategori }}
$$

Dimana $r=$ rentang nilai

Rentang nilai yang dibuat maksimal 3 merupakan pilihan jawaban tertinggi dikali jumlah responden sebanyak 75 , dan dikurangi nilai minimal 1 merupakan pilihan jawaban terendah dikali jumlah responden, lalu dibagi 3 yang merupakan 
rentang nilai yang dibuat sehingga 225$75 / 3=50$ menjadi berikut ini:

$\begin{array}{lll}\text { Kurang } & =75-124 \\ \text { Cukup/Sedang } & =125-174 \\ \text { Sangat } & =175-225\end{array}$

Karakteristik petani yang diukur meliputi usia, pendidikan, pengalaman, penghasilan, status petani yang diduga memiliki korelasi dengan partisipasi petani dalam program pemberdayaan yang yang dilaksanakan pada kegiatan yang bersifat sosialisasi dan implementasi yang dapat menggunakan chi square pearson test (Lastinawati, 2011):

$x^{2}=\sum \frac{\left(F_{o}+F_{e}\right)^{2}}{F_{e}}$

Dimana:

$\chi^{2}$ : chi square hitung

$\mathrm{F}_{\mathrm{o}}$ : Frekuensi observasi

$\mathrm{F}_{\mathrm{h}}$ : Frekuensi harapan

dengan hipotesis penelitian berikut:

Ho = terdapat korelasi antara usia, pendidikan, pengalaman, penghasilan, status petani dengan partisipasi petani dalam kegiatan sosialisasi atau implementasi.

$\mathrm{Ha}=$ tidak terdapat korelasi antara usia, pendidikan, pengalaman, penghasilan, status petani dengan partisipasi petani dalam kegiatan sosialisasi atau implementasi.
Untuk memperolah hasil pengujian chi square pearson pada penelitian ini dengan melihat nilai Exact Sig. (2-sided) bukan nilai Asymp. Sig. 2-sided) karena nilai Exact Sig. (2-sided) merupakan hasil eksak sehingga dapat mengabaikan syarat frekuensi harapan $>5$ (Gio \& Caraka, 2018). Adapun kriteria pada pengujian penelitian ini:

Nilai Exact. Sig. (2-sided) $<0,05$ maka $\mathrm{H}_{\mathrm{o}}$ diterima sehingga $\mathrm{H}_{\mathrm{a}}$ ditolak

Nilai Exact. Sig. (2-sided) > 0,05 maka $\mathrm{H}_{\mathrm{o}}$ ditolak sehingga $\mathrm{H}_{\mathrm{a}}$ diterima

Jika ingin mengetahui arah serta keeratan korelasi menurut (Simanjuntak et al., 2018) dapat dilakukan dengan uji gamma menggunakan kriteria: gamma $(\gamma)$ antara 0,10 sampai 0,29 terdapat korelasi lemah secara positif/negatif; gamma $(\gamma)$ antara 0,30 sampai 0,69 terdapat korelasi sedang secara positif/negatif; gamma $(\gamma)$ antara 0,70 sampai 1 terdapat korelas kuat secara positif/negatif.

\section{HASIL DAN PEMBAHASAN}

Pengumpulan data survei menggunakan instrumen kuesioner dilapangan telah dilaksanakan pada 4 Kecamatan terdiri atas Kecamatan Paseh, Kecamatan Cikancung, Kecamatan Pangalengan, dan Kecamatan Kertasari 
dengan jumlah sebanyak 75 orang petani responden dengan hasil sebagai berikut.

\section{Deskripsi Karakteristik Petani}

Tabel 1. Tingkat Usia Petani

\begin{tabular}{lccc}
\hline Tingkat Usia & Frekuensi & Persen & Skor \\
\hline $\begin{array}{c}\text { Tidak Produktif } \\
(>64)\end{array}$ & 14 & 18.7 & 14 \\
$\begin{array}{c}\text { Cukup Produktif } \\
(>49->64)\end{array}$ & 38 & 50.7 & 76 \\
$\begin{array}{c}\text { Sangat Produktif } \\
(>20-<49)\end{array}$ & 23 & 30.7 & 69 \\
\hline Total & 75 & 100 & 159 \\
\hline
\end{tabular}

Secara keseluruhan kategori petani di kabupaten bandung dengan total skor 159 berada pada kelompok usia yang cukup produktif. Sebanyak 50.7 persen petani berada pada tingkat usia produktif antara 50-64 tahun dan sebanyak 30.7 persen berada pada tingkat usia sangat produktif 20-49 tahun. Artinya secara fisik petani responden memiliki kemampuan yang cukup untuk melakukan pengembangan usahanya sebab menurut Palar et al., (2019) kemampuan dalam bekerja atau beraktivitas seseorang secara fisik dapat dipengaruhi oleh faktor umur, sementara ditemukan di lokasi penelitian petani memiliki kecenderungan berada pada kategori usia yang cukup produktif.

Tabel 2. Deskripsi Petani Berdasarkan Pendidikan Formal

\begin{tabular}{cccc}
\hline $\begin{array}{c}\text { Tingkat } \\
\text { Pendidikan }\end{array}$ & Frekuensi & Persen & Skor \\
\hline $\begin{array}{c}\text { Tidak Tamat } \\
\text { Sekolah } \\
\text { Tamat SD- } \\
\text { SMP }\end{array}$ & 2 & 2.7 & 2 \\
Tamat SMA & 46 & 61.3 & 92 \\
\hline & 27 & 36.0 & 81 \\
\hline
\end{tabular}

Dari survei diketahui sebanyak 36 persen petani memiliki pendidikan SMA dan secara umum karaktersitik petani berdasarkan pendidikan formal dapat dideskripsikan termasuk pada kateogori sangat baik. (Palar et al., 2019) Pendidikan menjadi salah satu diantara unsur penting dalam meningkatkan kualitas wawasan seseorang. Dengan demikian wawasan petani yang mengikuti program pemberdayaan yang dilakukan oleh ormas dapat dikatakan mampu untuk menerapkan inovasi yang akan meningkatkan dan mengembangkan usahanya sebab Safitri et al., (2020) menyebutkan petani akan semakin mudah menerapkan inovasi teknologi dengan semakin tinggi tingkat pendidikan petani, yang seharusnya memiliki korelasi positif bagi petani untuk dapat meningkatkan atau mengembangkan usahanya. Menurut Nugroho et al., (2018) meskipun sebagian besar usaha pertanian membutuhkan keterampilan, namun pendidikan memiliki korelasi yang positif terhadap pola pikir dalam memecahkan permasalahan. Hal tersebut berarti perlunya upaya peningkatan pengetahuan dan keterampilan usahatani melalui penyuluhan. 
Tabel 3. Deskripsi Petani Berdasarkan Penghasilan

\begin{tabular}{cccc}
\hline $\begin{array}{c}\text { Tingkat } \\
\text { Penghasilan } \\
\text { (Juta/Bulan) }\end{array}$ & Frekuensi & Persen & Skor \\
\hline Rendah $<1.5$ & 37 & 49.3 & 37 \\
Mengengah & 21 & 28.0 & 42 \\
$>1.5-3.5$ & 17 & 22.7 & 51 \\
Tinggi $>3.5$ & Total & & 130 \\
\hline
\end{tabular}

Adapun menurut deskripsi penghasilan petani diketahui sebanyak 49.3 persen petani yang menjadi responden memiliki tingkat penghasilan yang rendah meskipun secara keseluruhan dapat deskripsikan bahwa petani memiliki penghasilan perbulan berada pada kategori mengengah yang perlu ditingkatkan. Petani dengan penghasilan yang rendah dapat disebabkan oleh berbagai faktor diantaranya luas lahan (Wati et al., 2020), dan menurut hasil survei bahwa penghasilan yang rendah karena banyaknya petani yang berstatus sebagai petani penggarap.

Tabel 4. Deskripsi Petani Berdasarkan Pengalaman

\begin{tabular}{cccc}
\hline $\begin{array}{c}\text { Lama Bertani } \\
\text { (Tahun) }\end{array}$ & Frekuensi & Persen & Skor \\
\hline Kurang $(<5)$ & 7 & 9.3 & 7 \\
Cukup $(>5-$ & 20 & 26.7 & 40 \\
$<15)$ & 48 & 64.0 & 144 \\
Sangat $(>15)$ & Total & & 191 \\
\hline
\end{tabular}

Berdasarkan Tabel 4. Diketahui secara deskriptif karakteristik petani berdasarkan pengalaman lamanya dalam menjalankan usaha tani berada pada kategori sangat berpengalaman. Pengalaman usahatani akan mendorong cara pandang dan keputusan seseorang terhadap sesuatu yang perlu dilakukan (Yani et al., 2010). Dengan demikian semakin lama atau berpengalaman seorang petani akan mengarahkan kepada kemampuan menentukan keputusan yang paling efektif untuk dilaksanakan dalam usaha taninya.

Tabel 5. Deskripsi Petani Berdasarkan Status Petani

\begin{tabular}{cccc}
\hline Status Petani & Frekuensi & Persen & Skor \\
\hline Penggarap/ & 44 & 58.7 & 44 \\
Buruh & 11 & 14.7 & 22 \\
Penyewa & 20 & 26.7 & 60 \\
Pemilik & Total & 126 \\
\hline \multicolumn{3}{c}{}
\end{tabular}

Secara keseluruhan berdasarkan deskripsi petani sebagai responden berada pada kategori petani penyewa tetapi secara parsial menunjukkan ebanyak 58.7 persen petani yang menjadi responden merupakan petani penggarap. Banyaknya jumlah petani yang mnejadi petani penggarap akan mempengaruhi tingkat produktifitas usaha tani yang tentunya akan mengurangi kemanfaatan dari program yang dilaksanakan oleh pihak luar. Demikian Ramadoan et al., (2013) menyatakan adanya kejelasan status sebagai pemilik lahan akan menentukan aktifitas untuk meningkatkan kemanfaatan suatu kelompok tertentu. 


\section{PEMBERDAYAAN PETANI OLEH ORMAS MENURUT TINGKAT PARTISIPASI \\ DI KABUPATEN BANDUNG \\ Utan Sahiro Ritonga}

\section{Tingkat Partisipasi Petani}

Pengukuran tingkat partisipasi petani pada penelitian ini meliputi partisipasi pada kegiatan sosialisasi dan partisipasi pada kegiatan implementasi. Indikator partisipasi petani pada kegiatan sosialisasi dilakukan ormas meliputi keterlibatan petani dalam penyelenggaraan forum diskusi dan perencanaan, serta kegiatan sosialisasi lainnya yang berbentuk penyampaian informasi dan pengarahan pengetahuan petani. Sementara indikator partisipasi petani pada kegiatan implementasi meliputi keterlibatan petani dalam kegiatan penyuluhan dan pembinaan secara langsung atau menjalin kemitraan dengan ormas untuk memperoleh sarana produksi usaha tani, pemasaran produk dan termasuk keterlibatan petani pada berbagai kegiatan diluar dari hal teknis terkait usaha tani.

Tabel 6. Tingkat Partisipasi Petani Dalam Program Pemberdayaan

\begin{tabular}{|c|c|c|c|c|c|}
\hline \multirow{2}{*}{$\begin{array}{l}\text { Partisipasi } \\
\text { Kegiatan }\end{array}$} & \multicolumn{4}{|c|}{ Skor Partisipasi } & \multirow{2}{*}{ Kategori } \\
\hline & 3 & 2 & 1 & Total & \\
\hline Sosialisasi & 28 & 41 & 6 & 172 & Sedang \\
\hline Implementasi & 0 & 43 & 32 & 118 & Kurang \\
\hline
\end{tabular}

Berdasarkan Tabel 6. diketahui bahwa petani yang menjadi responden di lokasi penelitian menyebutkan petani selalu berpartisipasi dalam upaya ormas membangun kepedulian terhadap kegiatan pertanian di Kabupaten
Bandung. Petani mengikuti berbagai acara diskusi dan penyuluhan secara insidental yang dilakukan oleh institusi pendidikan tinggi yang dirancang oleh ormas. Alasan utama petani mengikuti kegiatan-kegiatan tersebut karena tokoh ormas Muhammadiyah di Kabupaten Bandung merupakan salah satu tokoh petani sukses.

Pada kegiatan implementasi diketahui tidak ada petani yang selalu berpartisipasi pada kegiatan kemitraan pemasaran produk karena petani kebanyakan hanya penggarap yang tidak dapat menetapkan kemana produk akan dijual dan demikian juga dengan upayaupaya penyediaan sarana produksi usaha tani yang difasilitasi oleh ormas Muhammadiyah melalui penyediaan bibit dan obat-obatan tetapi sebagian besar petani dalam kondisinya bukan pemilik usaha tapi hanya pelaksana yang tidak bisa mengambil keputusan. Menurut Rayuddin et al., (2010) diantara indikator yang berpengaruh terhadap rendahnya tingkat partisipasi petani pada kegiatan pembangunan pedesaan disebabkan kurangnya kesempatan petani, belum tepatnya sasaran program pemberdayaan petani, serta masalah keadilan (justice) yang diperoleh petani. Adapun karakteristik petani yang berkorelasi 
dengan tingkat partisipasi petani dapat dilihat pada Tabel 7 .

Tabel 7. Korelasi Karakteristik Petani Dengan Tingkat Partisipasi

\begin{tabular}{ccccc}
\hline \multirow{4}{*}{ Karakter } & \multicolumn{2}{c}{ Partisipasi } & \multicolumn{2}{c}{ Partisipasi } \\
& \multicolumn{2}{c}{ Sosialisasi } & \multicolumn{3}{c}{ Implementasi } \\
\cline { 2 - 5 } & $\begin{array}{c}\text { Exact } \\
\text { Sig. } \\
(2-\end{array}$ & Gamma & $\begin{array}{c}\text { Sig. } \\
\text { Sig- }\end{array}$ & Gamma \\
& sided $)$ & & sided $)$ & \\
\hline Usia & 0.306 & -0.059 & 0.000 & 0.251 \\
Pendidikan & 0.192 & 0.176 & 0.016 & -0.566 \\
Penghasilan & 0.565 & -0.121 & 0.001 & -0.649 \\
Pengalaman & 0.440 & 0.252 & 1.000 & 0.047 \\
Status & 0.055 & -0.366 & 0.002 & -0.481 \\
Petani & 0.056 & & &
\end{tabular}

Berdasarkan Tabel 7. diketahui usia, pendidikan, penghasilan dan pengalaman petani memiliki angka Exact Sig. (2-sided) $>0.05$ maka $\mathrm{H}_{\mathrm{o}}$ ditolak sehingga $\mathrm{H}_{\mathrm{a}}$ diterima, yang berarti tidak terdapat korelasi antara karakteristik petani dengan tingkat partisipasi petani dalam berbagai kegiatan sosialisasi. Usia petani yang secara keseluruhan dikatakan cukup produktif tidak memiliki korelasi dengan tingkat partisipasi petani dalam sosialisasi program, karena selama petani masih dapat melakukan aktifitas usaha tani akan berupaya memaksimalkan hasil dari usahanya dengan mengikuti berbagai kegiatan. Seperti yang disebutkan oleh Munfa'ati et al. (2017) kenyataan dilapangnan bahwa partisipasi pada tahap perencanaan tidak dipengaruhi oleh usia petani, karena petani yang berusia tua maupun muda memiliki kesempatan yang sama dalam merencanakan kegiatan. Tetapi usia petani pada penelitain ini memiliki korelasi positif lemah sebesar 0.251 dengan taraf kepercayaan hasil pengujian sebesar 99\%, yang artinya peningkatan partisipasi pada kegiatan sosialasi program mengikuti peningkatan jumlah petani yang memiliki usia sangat produktif yang memiliki rentang usia antara 20-49 tahun. Semakin banyak jumlah petani dengan usia produktif di suatu wilayah akan semakin meningkatkan partisipasi petani dalam melaksanakan program pemberdayaan yang meliputi kegiatan kemitraan dalam penyediaan input dan pemasaran output serta berbagai kegiatan pembinaan lainnya seperti pembinaan spiritual diluar dari unit kegiatan usaha tani itu sendiri.

Petani berpendidikan menengah keatas menurut Safitri et al., (2020) lebih mengetahui peran untuk bergabung pada kegiatan suatu kelompok dalam mengatasi bermacam masalah usaha tani. Berdasarkan hasil penelitian ini meskipun petani secara keseluruhan dapat dideskripsikan memiliki tingkat pendidikan yang sangat baik atau tingkat pendidikan menengah keatas, tetapi hasil pengujian menunjukkan tidak adanya korelasi antara tingkat pendidikan dengan partisipasi petani (Simanjuntak et al., 


\section{PEMBERDAYAAN PETANI OLEH ORMAS MENURUT TINGKAT PARTISIPASI \\ DI KABUPATEN BANDUNG \\ Utan Sahiro Ritonga}

2018). Tetapi tingkat pendidikan memiliki korelasi secara negatif yang cukup kuat sebesar -0.566 dengan partisipasi dalam kegiatan implementasi pada taraf kepercayaan pengujian sebesar $95 \%$, yang berarti meningkatnya partisipasi petani dalam kegiatan implementasi mengikuti penurunan dari banyaknya jumlah petani dengan pendidikan yang tinggi. Semakin banyak petani yang memiliki pendidikan dibawah tingkat sekolah menengah atas akan meningkatkan partisipasi petani dalam kegiatan implementasi, meskipun hal tersebut berbeda dengan yang disebutkan oleh Yani et al., (2010) bahwa pendidikan akan mendorong petani untuk bergabung pada kegiatan sebuah kelompok yang mempengaruhi berbagai perilaku, pola pikir, kreatifitas, dan keterampilan dalam melakukan usahatani dan hidup bermasyarakat.

Penghasilan petani menurut hasil survei berada pada kategori cukup dimana sebagian besar petani berpenghasilan rendah tidak memiliki korelasi dengan tingkat partisipasi pada kegiatan sosialisasi tetapi penghasilan petani memiliki korelasi yang negatif yang cukup kuat sebesar -0.649 yang dengan kegiatan implementasi pada taraf kepercayaan pengujian sebesar 99\%, dimana meningkatnya partisipasi petani dalam implementasi mengikuti penurunan banyaknya jumlah petani yang memiliki penghasilan yang tinggi. Semakin banyak petani dengan tingkat penghasilan dalam kategori menengah antara 1.5 sampai 3.5 juta per bulan akan meningkatkan partisipasi petani dalam kegiatan implementasi program.

Adapun pengalaman petani dengan lamanya mengelola usaha tani yang secara keseluruhan berada pada kategori sangat berpengalaman tidak memiliki korelasi dengan tingkat partisipasi baik untuk kegiatan sosialisasi program maupun implementasi. Safitri et al., (2020) menyebutkan lamanya usaha tani yang telah dijalankan tidak mempengaruhi keputusan petani bergabung pada kegiatan suatu kelompok. Umumnya petani dengan pengalaman lebih lama dapat lebih memahami segala aspek usaha taninya sehingga dapat merencanakan dengan lebih baik.

Sementara status petani pada lahan garapannya yang secara keseluruhan berada pada kategori sebagai petani penyewa dalam arti bekerja untuk melakukan aktivitas usaha dengan menyewa lahan tidak memiliki korelasi dengan partisipasi petani dalam kegiatan 
sosialisasi. Seperti yang dikemukakan Suindah et al. (2020) bahwa tidak ada korelasi status lahan garapan petani terhadap partisipasi petani dalam kegiatan untuk mengembangkan usaha taninya yang salah satunya dengan mengikuti asuransi. Tetapi dalam kondisi status petani sebagai penyewa dalam penelitian ini menunjukkan adanya korelasi negatif yang agak kuat sebesar 0.481 dengan partisipasi pada kegiatan implementasi pada taraf kepercayaan pengujian sebesar 99\%, yang berarti meningkatnya partisipasi petani terhadap kegiatan implementasi program mengikuti penurunan jumlah petani yang memiliki lahan sendiri untuk dikelola. Semakin banyak petani yang bukan petani pemilik lahan dan bukan buruh tani akan meningkatkan partisipasi petani dalam kegiatan implementasi program pemberdayaan. Petani pemilik dan petani penyewa akan berusaha untuk memaksimalkan hasil dari usaha taninya yang salah satu dapat dilakukan dengan berpartisipasi dalam kegiatan implementasi program pemberdayaan. Korelasi negatif status petani dalam pengelolaan lahan dengan partisipasi dalam kegiatan implementasi program pada penelitian ini mendukung hasil penelitian Ramadoan et al., (2013) bahwa terdapat korelasi negatif antara status lahan garapan terhadap peran sebuah kelompok untuk menjadi sarana belajar dan sarana peningkatan produksi bagi petani.

\section{KESIMPULAN DAN SARAN}

$\begin{array}{rrr}\text { Partisipasi } & \text { petani } & \text { menurut } \\ \text { keterlibatannya } & \text { dalam } & \text { program }\end{array}$
pemberdayan yang dilakukan oleh ormas masih perlu ditingkatkan. Kurangnya partisipasi petani dalam kegiatan implementasi kerjasama pemasaran dan penyediaan sarana produksi usaha tani karena banyaknya petani yang menjadi sasaran program adalah petani penggarap. Semakin banyak petani dengan usia produktif di suatu wilayah yang menjadi sasaran program pemberdayaan akan meningkatkan ketercapaian implementasi program karena usia petani memiliki korelasi positif dengan partisipasi petani dalam impelementasi. Sementara pendidikan, penghasilan dan status petani pada lahan garapannya memiliki korelasi negatif dengan partisipasi petani untuk mencapai implementasi program secara angka partisipasi. Semakin banyak petani yang memiliki pendidikan tetapi tidak pada jenjang pendidikan tinggi dapat meningkatkan partisipasi petani dalam implementasi. Semakin banyak jumlah 


\section{PEMBERDAYAAN PETANI OLEH ORMAS MENURUT TINGKAT PARTISIPASI \\ DI KABUPATEN BANDUNG \\ Utan Sahiro Ritonga}

petani berpenghasilan rendah dan berstatus sebagai petani penggarap yang menyewa lahan akan meningkatkan partisipasi petani dalam kegiatan implementasi.

Untuk mencapai tujuan pemberdayaan petani yang lebih efektif menurut angka partisipasi maka ormas perlu meninjau kondisi demografi petani meliputi karakteristik usia, pendidikan, penghasilan dan status petani. Dukungan pemerintah diperlukan melalui penyuluhan pemahaman berkelompok serta memberikan bantuan produksi usaha tani yang dapat menguatkan komitmen petani agar terlibat dan berpartisipasi secara penuh. Penelitian partisipasi petani dan peran ormas dalam pemberdayaan petani perlu terus dilakukan agar terjadi peningkatan efisiensi dan tercapai sinergi antara petani, pemerintah dan lembaga swasta yang berkelanjutan dalam aktifitas kesejahteraan sosial.

\section{UCAPAN TERIMA KASIH}

Penulis mengucapkan terimakasih kepada Majelis Diktilitbang PP Muhammadiyah （098.043/I.3/D/2019) dan Kemenristek/ BRIN (110/SP2H/LT/DRPM/2019).

\section{DAFTAR PUSTAKA}

Anantanyu, S. (2011). Kelembagaan Petani: Peran dan Strategi Pengembangan Kapasitasnya. SEPA, 7(2), 102-109. https://agribisnis.fp.uns.ac.id/wpcontent/uploads/2013/10/05-SapjaAnantanyu-Kelembagaan-PetaniPeran-Dan-Strategi-

Pengembangan-Kapasitasnya.pdf

Elizabeth, R. (2008). Partisipasi Sebagai Strategi Pemberdayaan Petani Miskin Melalui Program Integrasi Jagung dan Ternak. SOCA: Socioeconomics of Agriculture and Agribusiness, 8(1), 1-15.

Gio, P. U., \& Caraka, R. E. (2018). Pedoman Dasar Mengolah Data Dengan Program Aplikasi Statistika Statcal. USU Press. https://doi.org/https://doi.org/10.31 227/osf.io/796th

Hapsari, A., \& Kinseng, R. A. (2018). Hubungan Partisipasi Dalam Program Pemberdayaan UMKM Dengan Tingkat Kesejahteraan. Jurnal Sains Komunikasi Dan Pengembangan Masyarakat, 2(1), 1-12.

https://doi.org/10.29244/jskpm.2.1. $1-12$

Iqbal, M. (2007). Analisis Peran Pemangku Kepentingan dan Implementasinya Dalam Pembangunan Pertanian. Litbang Pertanian, 26(3), 89-99.

Jurdi, S. (2011). Muhammadiyah dan Gerakan Civil Society: Bergerak Membangun Kultur Madani. Sulesana, 6(2), 1-14.

Kehik, B. S. (2018). Pelaksanaan Program Pemberdayaan Masyarakat Desa di Bidang Ekonomi Kemasyarakatan (Studi Kasus di Desa Naiola Kecamatan Bikomi Selatan Kabupaten Timor Tengah Utara). Jurnal Agribisnis Lahan Kering, Agrimor, 3 No. 
1(2502), 4-6.

Lastinawati, E. (2011). Partisipasi Petani dalam Pelaksanaan Program Pengembangan Usaha Agribisnis Pedesaan (PUAP) di Kab. OKU. Agronobis, Vol.3 No.5(5), 45-57.

Mulyadi, M. (2012). Organisasi Masyarakat (Ormas) Dompet Dhuafa Dalam Perspektif Pemberdayaan Masyarakat. Aspirasi, 3(2), 167-178. https://doi.org/https://doi.org/10.22 212/aspirasi.v3i2.267

Mulyadi, M. (2015). Perubahan Sosial Masyarakat Agraris ke Masyarakat Industri Dalam Pembangunan Masyarakat di Kecamatan Tamalate Kota Makassar. Jurnal Bina Praja, 7(4), 311-322. https://doi.org/https://doi.org/10.21 787/jbp.07.2015.311-321

Munfa'ati, N., Lestari, E., \& Wijianto, A. (2017). Partisipasi Petani Dalam Program Seribu Hektar Sistem Tanam Padi Jajar Legowo di Kecamatan Karangpandan Kabupaten Karanganyar. Jurnal Agritexts, 41(1), 43-54.

Nugroho, F. M., Satmoko, S., \& Karno. (2018). Peran Kelompok Tani Terhadap Usahatani Padi Di Kecamatan Sale Kabupaten Rembang. Journal of Agro Complex, 2(2), 109-119. https://doi.org/10.14710/joac.2.2.10 9-119

Palar, R. H., Ngangi, C. R., \& Susana, B. O. L. (2019). Peran Kelompok Tani Terhadap Anggota Kelompok Tani Kelelelondei Indah di Desa Ampreng Kecamatan Langowan Barat. Agri-SosioEkonomi Unsrat, 15(1), 37-44. https://doi.org/https://doi.org/10.35 791/agrsosek.15.1.2019.22783

Priyono. (2016). Metode Penelitian Kuantitatif (T. Chandra (ed.); Revisi). Zifatama Publishing.
Putri, C. A., Anwarudin, O., \& Sulistyowati, D. (2019). Partisipasi Petani Dalam Kegiatan Penyuluhan dan Adopsi Pemupukan Padi Sawah di Kecamatan Kersamanah Kabupaten Garut. Jurnal Agribisnis Terpadu, 12(1), 103-119. https://doi.org/10.33512/jat.v12i1.5 538

Ramadoan, S., Muljono, P., \& Pulungan, I. (2013). Peran PKSM Dalam Meningkatkan Fungsi Kelompok Tani dan Partisipasi Masyarakat di Kabupaten Bima, NTB. Jurnal Penelitian Sosial Dan Ekonomi Kehutanan, 10(3), 199-210. https://ejournal.fordamof.org/latihan/index.php/JPSE/arti cle/view/177

Rayuddin, Zau, T., \& Ramli. (2010). Partisipasi Petani dalam Pembangunan Pedesaan di Kabupaten Konawe. Jurnal Penyuluhan, 6(1), 84-94. https://doi.org/10.25015/penyuluha n.v6i1.10671

Safitri, N., Istiqomah, Widayaningsih, N., \& Purnomo, S. D. (2020). Analisis Keanggotaan Petani Dalam Kelompok Tani: Studi Kasus Kelompok Pembudidaya Ikan "Ulam Sari" Desa Kalikidang, Sokaraja, Banyumas. Jurnal Sosial Ekonomi Pertanian, 13(1), 65-72.

Setyawan, D. (2013). Analisis Hubungan Ijtihad Dan Tajdid Pemikiran Ekonomi Terhadap Perkembangan Usaha (Studi kasus Pada Amal Usaha Organisasi Masyarakat Muhammadiyah). Jurnal Ekonomi Islam, 2(1), 105-134.

Simanjuntak, O. V., Subejo, S., \& Witjaksono, R. (2018). Partisipasi Petani Dalam Program Gerakan Penerapan Pengelolaan Tanaman Terpadu Padi di Kecamatan Kalasan Kabupaten Sleman. Agro Ekonomi, 27(1), 20. 
https://doi.org/10.22146/jae.22693

Sriati, Hakim, N., \& Arbi, M. (2017).

Partisipasi Petani dan Efektivitas

Gapoktan dalam Penguatan

Lembaga Distribusi Pangan

Masyarakat (LDPM) di Kecamatan

Makarti Jaya Kabupaten

Banyuasin. Jurnal Penyuluhan, 13(1), 88-96.

https://doi.org/10.25015/penyuluha n.v13i1.14206

Suindah, N. N., Darmawan, D. P., \& I Ketut Suamba. (2020). Analisis Faktor-Faktor Yang Memengaruhi Partisipasi Petani Dalam Asuransi Usahatani Padi (AUTP) di Kecematan Penebel Kabupaten Tabanan. Agrisocionomics: Jurnal Sosial Ekonomi Pertanian, 4(1), 21-32.

Sukanata, I. K., Dukat, \& Yuniati, A. (2015). Hubungan Karakteristik dan Motivasi Petani Dengan Kinerja Kelompok Tani (Studi Kasus Desa Cisaat Kecamatan Dukupuntang). Agrijati, 28(1), 1734.

Suparman, D. (2012). KewirausahaanSosial Berbasis Organisasi Masyarakat Ormas (Studi Analisis mengenai Pemberdayaan Ekonomi Ummat atas Unit Usaha-Sosial Persis, NU, dan Muhammadiyah di Kabupaten Garut). Istek, VI(1), 158-164.

http://journal.uinsgd.ac.id/index.ph p/istek/article/download/299/313

Suprayitno, A. R., Sumardjo, Gani, D. S., \& Sugihen, B. G. (2015). Motivasi dan Partisipasi Petani dalam Pengelolaan Hutan Kemiri di Kabupaten Maros Provinsi
Sulawesi Selatan. Jurnal Penyuluhan, 8(2), 182-196. https://doi.org/10.25015/penyuluha n.v8i2.9883

Syahyuti. (2012). Pengorganisasi Secara Personal dan Gejala Individualisasi Organisasi Sebagai Karakter Utama Pengorganisasi Diri Petani di Indonesia. Forum Penelitian Agro Ekonomi, 30(2), 129-145.

Wati, F., Rasmikayati, E., \& Saefudin, B. R. (2020). Analisis Hubungan Karakteristik Anggota Kelompok Tani Dengan Penerapan Teknologi Off Season Pada Kegiatan Usahatani Mangga di Kecamatan Sedong, Kabupaten Cirebon, Jawa Barat. Jurnal Ekonomi Pertanian Dan Agribisnis, 4(4), 715-727. https://doi.org/https://doi.org/10.21 776/ub.jepa.2020.004.04.02

Widjajanti, K. (2011). Model Pemberdayaan Masyarakat. Jurnal Ekonomi Pembangunan, 12(1), 1527.

Yani, D. E., ES, L., \& Noviyanti, R. (2010). Persepsi Anggota Terhadap Peran Kelompok Tani Dalam Meningkatkan Kemampuan Penguasaan Teknologi Budidaya Belimbing. Jurnal Matematik, Sains, Dan Teknologi, 11(2), 133145.

http://jurnal.ut.ac.id/index.php/jmst/ article/view/575

Zakaria, A. K. (2010). Kebijakan Pengembangan Budidaya Kedelai Menuju Swasembada Melalui Partisipasi Petani. Analisis Kebijakan Pertanian, 8(3), 259272. 